Ya. Litvinova ${ }^{1}$, Cand. Sc. (Tech.), orcid.org/0000-0003-2806-4076, K. Nosal-Hoy ${ }^{2}$, PhD, orcid.org/0000-0002-7221-5487, K. Solecka ${ }^{2}$, PhD, orcid.org/0000-0002-8796-7729, I. Taran ${ }^{1}$, Dr. Sc. (Tech.), Prof., orcid.org/0000-0002-3679-2519
1 - Dnipro University of Technology, Dnipro, Ukraine, e-mail: taran7077@gmail.com

2 - Cracow University of Technology, Kraków, Poland, e-mail: knosal@pk.edu.pl

\title{
IMPROVEMENT OF EFFICIENCY OF PROCESSES OF MINING PRODUCT PROCESSING AT TRANSPORT HUBS
}

Purpose. Improvement of efficiency of processes of overloading products of mining enterprises at transport hubs. Substantiation of directions of optimization of logistic management processes and optimal characteristics of production resources and organizational influences at logistic management at a multimodal transport hub. Determination of economic effect from substantiation of these characteristics.

Methodology. Mathematical modeling methods and a systematic approach were used to formalize the object of study. Simulation modeling techniques were used to develop the model of the research object. In order to determine the dependence of the efficiency criterion of transport node operation on the parameters of material flows and numerical characteristics of production resources, regression analysis methods were applied.

Findings. Based on the study, it is proposed to use a specific measure of efficiency, which is the ratio of profit from customer service at the transport hub to the cost of production resources involved in the process of service. On the basis of the developed model of the transport node, it is possible to solve the aimed tasks for the improvement of logistic management and processing of products of mining enterprises at transport hubs.

Originality. An approach to improvement of logistic management of transport hubs at the expense of substantiation of optimal parameters of production resources and selection of the most effective version of technological process of customer service is offered.

Practical value. It consists in the development of approaches to determining the most effective version of servicing material flows, as well as to determining the optimal numerical characteristics of production resources of a transport node.

Keywords: regional systems; logistic management, transport node, material flow, mining enterprises

Introduction. The current level of development of transport systems, against a background of Ukraine's integration into the European and world economic system, is ensured by the rapid growth of relevant regional elements. One of such elements of transport systems is transport hubs, which ensure the promotion of material flows due to their consolidation and distribution in the directions, ensuring the possibility of transshipment of goods for different types of transport and intermediate storage of consignments of goods. Another important factor for the development of these systems is the geographical location of Ukraine, which is reflected in the opportunities for the development of transport hubs, and especially in the export of minerals, whose volumes are increasing every year. This must inevitably correlate with the capacity of the transport infrastructure in accordance with European requirements. One of the ways to provide the necessary bandwidth is appropriate logistic management of technological processes of the transport node, which involves the coordination of work of different modes of transport and the interaction of all elements of the transport node to reduce the cost of material flows, subject to restrictions on the time of operations and available production resources. The functioning of transport hubs is characterized by the influence of a large number of random factors, both external and internal, on technological processes. Thus, the scientific direction of creation of new models of functioning of transport nodes with the use of modern mathematical methods and information technologies is relevant, and the use of the obtained results allows increasing the efficiency of logistic management processes.

Literature review. The vast majority of well-known scientists have paid their attention to the necessity of developing transport logistics at the regional level. For example, in [1, 2], the conceptual aspects of the operation of transport nodes are emphasized. The transport and logistic system of the region is

(C) Litvinova Ya., Nosal-Hoy K., Solecka K., Taran I., 2020 one of the most important factors of economic growth, which can be hindered by the presence of "bottle-necks" in the transport infrastructure [3].

Different types of transport, which interact at transport nodes, include, in particular, river transport [4]. The availability, although somewhat outdated, of a strong infrastructure base, a convenient geographical location creates the preconditions for the renewal of this transport route [5]. Attention should also be paid to the development of rail transport [6], which, as European experience shows, has many advantages over road transport [7] and is capable of increasing the efficiency of customer transport at the junctions [8]. The development of transport with the participation of Ukrainian railways [9] is promising given the signed Association Agreement between Ukraine and the EU (it contains a clause on the development of multimodal and combined transport and Directive 92/106/EEC to be implemented by Ukraine), as well as a definite European integration vector for the development of Ukraine, where freight rail transport is stimulated at all levels due to its environmental and energy efficiency compared to road transport [10]. The authors of the article also emphasized that it is multimodal transportations that provide coordination and organizational and technological interaction of all links of the freight delivery chain, which contributes to the complex development of infrastructure of different modes of transport [11].

The analysis of scientific works on increasing the efficiency of transport management is a preliminary step in conducting research in the field of transport systems functioning [12, 13]. The results of the analysis of modern scientific works on the improvement of the processes of managing the work of transport nodes on the basis of logistical principles allowed distinguishing a number of characteristic features. For example, [14] proposes a technique where a minimum of transportation, storage, and rebuilding costs are used as a criterion for optimality. It should be noted that [15] proposes a macroecono- 
mic approach, which requires clear production and transport service plans. This approach is not relevant in a market economy, so the use of such management models at transport nodes is possible only after they have been refined in the light of the random nature of demand for production and transport services. It should be noted that imitation modeling as a methodology for solving the problems of managing the work of transport nodes has become widespread in theoretical developments [16, 17].

The accomplished analysis shows the aim of streamlining the flow of processes within a managed system from the point of view of a single supply chain, the integration of which is carried out at the technical, technological, economic, methodological levels, and minimizing the cost of time and resources is achieved by optimizing through control material, information and financial flows.

In theoretical developments that use economic performance indicators as the criterion of efficiency, the most commonly used are the total costs: costs of cargo owners, macroeconomic costs, the amount of transport and storage costs, the cost of delay in the execution of technological operations, the amount of transportation costs, storage and adjustment of production programs, total costs of the logistic system, transportation costs. In addition, profit or its derivatives are also used as economic indicators of efficiency. Therefore, models of improvement of technological processes of interaction of different types of transport at the nodes should have software implementation in the form of modules of modern information systems [18].

Unsolved aspects of the problem. The emergence of problematic situations in the process of operation of transport nodes is due to the partial or completely absent systematic approach to the management of the nodes as logistic systems. Taking into account a number of problematic situations arising in the process of cargo flow processing at transport hubs, as well as the reasons for their occurrence, it is advisable to optimize the structure and capacity of production facilities of transport hubs, taking into account the parameters of demand for cargo processing services.

Purpose. Increasing the efficiency of logistic management processes for different types of transport, storage and processing of products of mining enterprises at transport hubs. Substantiation of directions of optimization of logistic management processes and optimal numerical characteristics of production resources and organizational influences in logistic management at a multimodal transport hub and determination of economic effect from substantiation of these characteristics.

Results. Transport nodes are structural elements of logistics chains, and in their composition - elements of technological systems of cargo delivery, which are a set of technical, technological, commercial, legal solutions that are implemented with the involvement of many intermediaries, most often - several modes of transport. Accordingly, the efficiency of the operation of transport nodes affects the efficiency of individual logistic chains of cargo delivery, and in general - the efficiency of macro-logistic systems in the regions. Analyzed existing economic indicators do not take into account the interests of all actors of the transport process, and quality indicators, in turn, do not take into account the complex of both technical features and cost indicators, which does not allow using them to evaluate the efficiency of transport nodes in solving dedicated optimization tasks.

When solving problems of optimization of the structure and capacity of production facilities of transport hubs as elements of macro-logistic systems, it is proposed to use a specific indicator of efficiency $\mathrm{K}_{\mathrm{e}}$, which is the ratio of profit from customer service in the transport node to the cost of production resources involved in the process of maintenance

$$
K_{e}=\frac{T_{1 t} \cdot Q-E_{\Sigma}}{C_{R}}
$$

where $Q$ is the total volume of cargo that has been overloaded at the transport node during a given period, $\mathrm{t} ; T_{1 t}$ is a tariff for processing 1 ton of cargo at the transport junction, $\mathrm{UAH} / \mathrm{t} ; E_{\Sigma}$ are total costs for servicing the clientele in the transport hub during the specified period, $\mathrm{UAH} ; C_{R}$ is the total cost of production resources used in the process of material flow processing, UAH.

This criterion contains a standard in the practice of logistic management indicator (total cost of maintenance), but it allows taking into account the internal system characteristics (cost of production resources). It should be noted that the total costs are functionally dependent on the parameters of demand and parameters of the intra-system material, financial and information flows.

For an accepted criterion, an increase in the efficiency of the operation of a transport node means an increase in the value of the efficiency criterion for the proposed version of the organization of customer service compared to the existing (basic) version. That is, the task of increasing the efficiency of the operation of the transport node is considered to be realized if the following control parameters are defined, which fulfills the following condition

$$
K_{e}\left(R_{X}^{\prime \prime}, M_{X}^{\prime \prime}, D_{Z}\right)>K_{e}\left(R_{X}^{\prime}, M_{X}^{\prime}, D_{Z}\right),
$$

where $R_{X}^{\prime \prime}, M_{X}^{\prime \prime}$ are numerical characteristics of production resources and organizational impacts, respectively, for the advanced version of the operation of the transport node; $R_{X}^{\prime}$, $M_{X}^{\prime}$ are numerical characteristics of production resources and organizational impacts, respectively, for the basic version of operation of the transport node.

The following statement can be used as a working hypothesis: there are the following values of the numerical characteristics of the control parameters $R_{X}$ and $M_{X}$, which for the given parameters of the $D_{Z}$ demand provide the highest possible value of the efficiency criterion. To test the working hypothesis, it is necessary to determine the functional dependency. If the working hypothesis is not rejected, then the task of improving logistic management in the transport node can be defined as optimization (maximization of the objective function)

$$
K_{e}\left(R_{X}, M_{X}, D_{Z}\right) \rightarrow \text { max. }
$$

As the main subsystems of the process of servicing the clientele in the transport node, the following elements (subprocesses) should be identified: $E_{1}-$ maintenance of incoming material flow at the front of cargo works with unloading at the warehouse of the transport node; these operations are carried out on the fronts of cargo works of the "transport - warehouse" type (TW); $E_{2}$ - intermediate storage of cargoes at warehouses of transport node; $E_{3}$ - maintenance of the outbound material flow at the front of cargo works with loading vehicles from the warehouse of the transport node; these operations are carried out on the fronts of cargo works of the "warehouse - transport" type (WT); $E_{4}-$ maintenance of inbound and outbound material flows at the front of cargo works with direct preloading from a vehicle of one mode of transport to a vehicle of another mode of transport; these operations are carried out on the fronts of cargo operations of "transport transport" type (TT).

The links between the elements of the transport node functioning in the models are described by functional dependencies or algorithms. Dependency indicates that there is a connection and vice versa. Depending on the accepted option of servicing the input and output material flow, there are three versions for organizing the technological process of functioning of transport nodes. To estimate the demand for the services of a transport hub, it is sufficient to describe the flow of applications by the numerical characteristics of the time of receipt of applications, the unit cost of a vehicle and the volume of cargo to be unloaded or loaded, using the method described by 
the author in [19]. The study examines the transport hub of Zaporizhzhia River Port, in which technological processes of interaction of three modes of transport - river, railway and automobile - are carried out and are a promising platform for the overloading of products of mining enterprises. The prospect of development of the port is attested by its location, namely, in the field of mining operations and the presence of constantly increasing volumes of commodity flows, in particular volumes of processing of goods by river and sea transport, structure of export and import of goods [20].

The demand parameters for inbound and outbound material flows were investigated for off-loading fronts (unloading fronts for rail and road transport, as well as loading fronts for river transport) of Zaporizhzhia River Port in the period of navigation in 2018 year from March to November. During the period indicated, 623 applications were identified for the unloading front for road transport, 502 for the unloading front for rail transport, and 108 applications for the front loading of river transport vehicles. Demand for overloading and storage of ore minerals transport node is active during the navigation period. The minimum and maximum value of the characteristic is taken according to the initial data. Characteristics of samples of random values of parameters of requests flows are presented in Table.

A check of the laws of distribution of demand parameters for services of a transport node, conducted using Pearson's criterion, showed that the volume of a consignment is a normally distributed quantity and the interval of receipt of re- quests in the flow has an exponential distribution regardless of the mode of transport. In order to provide a statistically correct estimation of the influence of the input parameters on the criterion of efficiency of multimodal transport node functioning, it was decided to carry out a full-factorial experiment.

The following numerical characteristics of the transport node's production resources and the parameters of input and output material flows are considered as input factors in a fullscale simulation experiment: $n_{i g}$ and $n_{o g}-$ the number of mechanisms involved in servicing the input and output material flows, respectively; $\varphi_{w h}-$ the capacity of the transport node, $\mathrm{t}$ (reduced to warehouse area using the warehouse area utilization ratio $\left.\alpha_{w h}\right) ; \mu_{i \omega}$ and $\mu_{o \omega}$ - mathematical expectation of the value of the consignment for the incoming stream (the consignment must be unloaded at the transport node) and the output stream (the consignment must be loaded at the transport node), respectively, $\mathrm{t} ; \mu_{i \zeta}$ and $\mu_{o \zeta}$ - mathematical expectation of the magnitude of the flow of applications in the input and output streams, respectively, year.

The results of the simulation experiment were analyzed using the MS Excel tool (Data $\rightarrow$ Data Analysis $\rightarrow$ Regression). At the same time, the level of maintenance of the request flow and the total cost of maintenance of the material flow in the transport node are considered as response functions. For example, the following is a set of hypotheses about the type of functional dependence on input factors in the option of servicing the material flow with direct overload from one vehicle to another

$$
\left[\begin{array}{l}
H_{1}: R_{D}=a_{n} \cdot n_{g}+a_{i \omega} \cdot \mu_{i \omega}+a_{o \omega} \cdot \mu_{o \omega}+a_{i \zeta} \cdot \mu_{i \zeta}+a_{o \zeta} \cdot \mu_{o \zeta} \\
H_{2}: R_{D}=n_{g}^{a_{n}} \cdot \mu_{i \omega}^{a_{i \omega}} \cdot \mu_{o \omega}^{a_{o \omega}} \cdot \mu_{i \zeta}^{a_{\zeta \zeta}} \cdot \mu_{o \zeta}^{a_{o \zeta}} \\
H_{3}: R_{D}=a_{n} \cdot \ln n_{g}+a_{i \omega} \cdot \ln \mu_{i \omega}+a_{o \omega} \cdot \ln \mu_{o \omega}+a_{i \zeta} \cdot \ln \mu_{i \zeta}+a_{o \zeta} \cdot \ln \mu_{o \zeta} \\
H_{4}: R_{D}=a_{n} \cdot \ln n_{g}+a_{i \omega} \cdot \mu_{i \omega}+a_{o \omega} \cdot \mu_{o \omega}+a_{i \zeta} \cdot \ln \mu_{i \zeta}+a_{o \zeta} \cdot \ln \mu_{o \zeta}
\end{array},\right.
$$

where $a_{i n}, a_{o n}, a_{\varphi}, a_{i \omega}, a_{o \omega}, a_{i \zeta}, a_{o \zeta}$ are the coefficients of the regression models of the service level; $a_{n}$ is the coefficient of regression model of the level of service at the input factor of the number of servicing mechanisms $n_{g}$.

The obtained regression models make it possible to formalize the dependence of the criterion of logistic management efficiency in transport nodes on the input control parameters the numerical characteristics of production resources, for different options for maintenance of material flow. The estimation of the optimal numerical parameters of production resources is carried out taking into account the functional dependence (2) and the corresponding dependencies in the overloading of loads through the warehouse and in a mixed way as the value of the arguments for the corresponding extrema of the function (1).

The choice of the optimal version of the process of maintenance of material flow in the transport node is carried out on the basis of the criterion of efficiency of functioning of the transport node

$$
\psi_{\text {opt }}=\underset{\psi=\{W H, D, M\}}{\arg } \max \left\{K_{e}^{W H}\left(R_{X}^{W H}, D_{Z}\right), K_{e}^{D}\left(R_{X}^{D}, D_{Z}\right), K_{e}^{M}\left(R_{X}^{M}, D_{Z}\right)\right\},
$$

where $K_{e}^{W H}, K_{e}^{D}, K_{e}^{M}$ are the value of the criterion of the efficiency of the operation of the transport node for the option through the warehouse (WH), direct transshipment (D) and mixed service version $(\mathrm{M})$, respectively.

The calculations showed that for the cargo area of Zaporizhzhia river port the most effective version of servicing material flow is the use of mixed technology, with the optimum number of servicing mechanisms equal to 5 , and the optimal storage capacity is $1560 \mathrm{t}$.

The economic effect of choosing the version of servicing the material flow in the transport junction and justifying the amount of production resources involved in the maintenance process is performed on the basis of the proposed efficiency criterion in the following cases:

- rationalization of the parameters of functioning of existing transport nodes - relative to the characteristics of the adopted technological scheme of service;

- when substantiating the technological process parameters of the transport nodes that are being created, - with respect to alternative version of the material flow maintenance process.

For existing transport nodes, the economic effect is calculated as the difference between the efficiency criterion for the proposed process version and the existing version

Characteristics of request flow parameter samples

\begin{tabular}{|l|c|c|c|c|c|c|}
\hline \multirow{2}{*}{ Characteristics } & \multicolumn{2}{|c|}{ Unloading front (cars) } & \multicolumn{2}{c|}{ Unloading front (railway cars) } & \multicolumn{2}{c|}{ Load front (river vessels) } \\
\cline { 2 - 8 } & $\begin{array}{c}\text { consignment } \\
\text { volume, } \mathrm{t}\end{array}$ & $\begin{array}{c}\text { Interval receipts } \\
\text { applications, year }\end{array}$ & $\begin{array}{c}\text { consignment } \\
\text { volume, } \mathrm{t}\end{array}$ & $\begin{array}{c}\text { Interval receipts } \\
\text { applications, year }\end{array}$ & $\begin{array}{c}\text { consignment } \\
\text { volume, } \mathrm{t}\end{array}$ & $\begin{array}{c}\text { Interval receipts } \\
\text { applications, year }\end{array}$ \\
\hline Mathematical expectation & 16.46 & 2.01 & 522.65 & 13.56 & 850.23 & 13.61 \\
\hline Middle quadratic deviation & 2.26 & 0.42 & 154.41 & 7.60 & 29.02 & 2.05 \\
\hline
\end{tabular}




$$
\varepsilon_{f}=K_{e}\left(\psi_{\text {opt }}, R_{X}^{\text {opt }}, D_{Z}\right)-K_{e}\left(\psi_{0}, R_{X}^{0}, D_{Z}\right),
$$

where $\psi_{\text {opt }}, \psi_{0}$ are the most effective and accepted versions for the maintenance of material flow, respectively; $R_{X}^{\text {opt }}, R_{X}^{0}$ are the optimal and acceptable numerical characteristics of the production resources of the transport node.

In absolute terms, the economic effect is proposed to be estimated as the difference of profit of the multimodal transport hub for the planned period, which corresponds to the optimal and basic value of the efficiency criterion

$$
\Delta \Pi=\frac{T_{1 t} \cdot T_{m} \cdot\left(\mu_{i \omega} \cdot \mu_{o \zeta}+\mu_{o \omega} \cdot \mu_{i \zeta}\right)}{\mu_{i \zeta} \cdot \mu_{o \zeta}} \cdot\left(R_{o p t}-R_{0}\right)-E_{o p t}+E_{0},
$$

where $T_{m}$ is the period during which the operation of the transport hub is considered, year; $R_{o p t}$ and $R_{0}$ are the levels of service flow of applications for the optimal version of operation of the transport node and the base version, respectively; $E_{\text {opt }}$ and $E_{0}$ are the total costs of maintaining the flow of applications for the optimal version of operation of the transport node and the base version, respectively, \$.

The economic effect of substantiating the optimal amount of production resources and selecting the most efficient version of technological process for Zaporizhzhia River Port is evaluated in the paper. The transportation hub is an operating company that uses the technology of warehouse overload services. In this case, 3 servicing mechanisms are involved at the ore unloading front, 2 mechanisms at the loading front, and the capacity of the warehouse used to serve the clientele is $1700 \mathrm{t}$. According to the results of calculations (3), (4), the effect of justifying the optimal number of production resources and selecting the most efficient version of technological process for Zaporizhzhia River Port is 0.28 ; such an increase in the efficiency criterion allows increasing the profit of the enterprise from the customer service by about $\$ 115$ thousand/month.

Conclusions. The analysis of the theoretical principles allows us to confirm that there is a great interest of business and authorities in coordinating the work of different modes of transport and the interaction of all elements of the transport node of the river port in order to increase the efficiency of their work. The focus is on regional development of the interaction of different types of transport in river ports as a determining factor for the European integration vector of Ukraine's development. Also, the analysis conducted allowed stating that a large number of parameters of a random nature have to be taken into account when modeling the processes of servicing cargo owners at transport hubs. Existing theoretical developments, as a rule, are not widely used in the practice of logistic management due to the lack of specialized software that implements relevant optimization and rationalization models, as well as methodological guidance of a practical nature.

The results of the regression model experiment obtained on the basis of the analysis allow us to formalize the dependence of the criterion of logistic management efficiency in transport nodes on the input control parameters for different material flow maintenance versions. The results of the analysis of the regression models made it possible to obtain dependencies to substantiate the numerical characteristics of production resources and organizational influences during logistic management at a multimodal transport hub. The results of the analysis for Zaporizhzhia river port showed that the most efficient version of service is the use of mixed technology, with 5 loading and unloading mechanisms being involved, and the optimal storage capacity should be $1560 \mathrm{t}$.

The proposed methodology of determining the economic effect of the choice of material flow maintenance and justification of the number of production resources involved in the process of servicing, allows evaluating the economic effect in rationalizing the parameters of functioning of existing trans- port nodes, as well as in justifying the parameters of technological process of transport nodes that are created. The economic effect of justifying the optimal amount of production resources and selecting the most efficient version of technological process for Zaporizhzhia River Port is 0.28 . This increase in the efficiency criterion allows increasing the monthly profit of the enterprise from customer service by about \$ 115 thousand.

\section{References}

1. Shramenko, N., \& Muzylyov, D. (2020). Forecasting of Overloading Volumes in Transport Systems Based on the Fuzzy-Neural Model. In: Ivanov, V., Trojanowska, J., Machado, J., Liaposhchenko, O., Zajac, J., Pavlenko, I., ... Perakovic, D. (Eds.) Advances in Design, Simulation and Manufacturing II. DSMIE 2019. Lecture Notes in Mechanical Engineering. Springer, 311-320.

2. Turpak, S. M., Taran, I. O., Fomin, O.V., \& Tretiak, O. O. (2018). Logistic technology to deliver raw material for metallurgical production. Naukovyi Visnyk Natsionalnoho Hirnychoho Universytetu, (1), 162-169. https://doi.org/10.29202/ nvngu/2018-1/3.

3. Korniyetskyy, O. V. (2015). Theoretical Basis for the Development of Regional and Interregional Transport and Logistic Systems. Business navigator, 1(36), 107-112.

4. Sładkowski, A., \& Cieśla, M. (2015). Influence of a potential railway line connecting the Caspian Sea with the Black Sea on the development of Eurasian trade. Nase More, 62(4), 264271. https://doi.org/10.17818/NM/2015/4.4.

5. Okorokov, A. M., Vernigora, R. V., \& Tsuprov, P. S. (2016). River transport of Ukraine: current state and prospects. Transport Systems and Transportation Technologies, (12), 62-68. https://doi.org/10.15802/tstt2016/85886.

6. Taran, I. A. (2012). Interrelation of circular transfer ratio of double-split transmissions with regulation characteristic in case of planetary gear output. Naukovyi Visnyk Natsionalnoho Hirnychoho Universytetu, (3), 75-85.

7. Kravets, V.V., Sakhno, V.P., Bass, K. M., \& Kravets, V.I. (2018). Program spatial movement of high-speed vehicles. IOP Conference Series: Materials Science and Engineering, 383(1), 012032. https://doi.org/10.1088/1757-899X/383/1/012032.

8. Okorokov, A. M. (2015). Analysis of the prospects development container market in ukraine. Transport Systems and Transportation Technologies, O(10), 98. https://doi.org/10.15802/ tstt2015/57075.

9. Alyoshinsky, Ev.S., Svitlychna, S. O., \& Bagno, A. M. (2014). Investigation of possible variants of delivery of international freight traffic in mixed traffic within the transport system of Ukraine. Collection of Scientific Works of the Ukrainian State Academy of Railway Transport, 144. 45-49.

10. Kozachenko, D., Skalozub, V., Gera, B., Hermaniuk, Yu., Korobiova, R., \& Gorbova, A. (2019). A model of transit freight distribution on a railway network. Transport Problems, 14(3), 17-26. https://doi.org/10.20858/tp.2019.14.3.2.

11. Sokolova, O. Ye. (2014). Conceptual bases of formation of multimodal transportation system. Naukoiemni tekhnolohii, 1, 114-118.

12. Sładkowski, A., Utegenova, A., Kolga, A.D., Gavrishev, S. E., Stolpovskikh, I., \& Taran, I. (2019). Improving the efficiency of using dump trucks under conditions of career at open mining works. Naukovyi Visnyk Natsionalnoho Hirnychoho Universytetu, (2), 36-42. https://doi.org/10.29202/nvn$\mathrm{gu} / 2019-2 / 8$.

13. Vuyeykova, O., Sładkowski, A., Stolpovskikh, I., \& Akhmetova, M. (2016). Rationalization of Road Transport Park for the Carriage of Mining Rocks in the Open Mines. Transport Problems, 11(1), 79-85. https://doi.org/10.20858/tp.2016.11.1.8.

14. Nagorny, Ye., Naumov, V., \& Ivanchenko, A. (2012). Analysis of modern approaches of increasing the efficiency of international cargo delivery logistics systems. Transport systems and delivery technologies, 3, 68-72. 
15. Shramenko, N., Pavlenko, O., \& Muzylyov, D. (2019). Information and Communication Technology: Case of Using Petri Nets for Grain Delivery Simulation at Logistics System. CEUR Workshop Proceedings, 2353, 935-949.

16. Naumov, V. (2017). Estimating the Vehicles' Number for Servicing a Flow of Requests on Goods Delivery. Transportation Research Procedia, 27, 412-419. https://doi.org/10.1016/j. trpro.2017.12.063.

17. Nagorny, Ye., Naumov, V., \& Ivanchenko, A. (2012). Model of a cargo delivery logistics system between Ukraine and Belarus. Transport systems and delivery technologies, 4, 70-74. 18. Demydenko, M. (2018). Method of selection of ERP systems using multi-criterial optimization models. Naukovyi Visnyk Natsionalnoho Hirnychoho Universytetu, (5), 132-137. https://doi.org/10.29202/nvngu/2018-5/21.

19. Naumov, V., Nagornyi, I., \& Litvinova, Y. (2015). Model of multimodal transport node functioning. Archives of Transport, 36(4), 43-54. https://doi.org/10.5604/08669546.1185202. 20. Lyfar, V. V. (2017). Development of transport logistics in the regional system of commodity flows service. Marketing and Management of Innovations, (4), 176-187. https://doi. org/10.21272/mmi.2017.4-15.

\section{Підвищення ефективності процесів переробки продукції гірничодобувних підприємств у транспортних вузлах}

\section{Я. Літвінова ${ }^{1}$, К. Носаль-Хой ${ }^{2}$, К. Солецька ${ }^{2}$, I. Таран $^{1}$ \\ 1 - Національній технічний університет «Дніпровська політехніка», м. Дніпро, Україна, e-mail: taran7077@ gmail.com \\ 2 - Краківський технічний університет, м. Краків, Поль- ща, e-mail: knosal@pk.edu.pl}

Мета. Підвищення ефективності процесів перевантаження продукції гірничодобувних підприємств у транспортних вузлах. Обгрунтування напрямів оптимізації процесів логістичного управління та оптимальних характеристик виробничих ресурсів і організаційних впливів при логістичному управлінні в мультимодальному транспортному вузлі. Визначення економічного ефекту від обгрунтування цих характеристик.

Методика. Для формалізації об’єкта дослідження застосовані методи математичного моделювання й системний підхід. Для розробки моделі об’єкту дослідження використані методи імітаційного моделювання. 3 метою визначення залежності критерію ефективності функціонування транспортного вузла від параметрів матеріальних потоків і чисельних характеристик виробничих ресурсів застосовані методи регресійного аналізу.

Результати. На підставі проведеного дослідження запропоновано використовувати питомий показник ефективності, що є відношенням прибутку від обслуговування клієнтури у транспортному вузлі до вартості виробничих ресурсів, які задіяні у процесі обслуговування. На підставі розробленої моделі транспортного вузла можливим $€$ вирішення поставлених задач з удосконалення логістичного управління й переробки продукції гірничодобувних підприємств у транспортних вузлах.

Наукова новизна. Запропоновано підхід до удосконалення логістичного управління транспортним вузлом за рахунок обгрунтування оптимальних параметрів виробничих ресурсів і вибору найбільш ефективного варіанту технологічного процесу обслуговування замовників.
Практична значимість. Полягає в розробці підходів до визначення найбільш ефективного варіанту обслуговування матеріальних потоків, а також у визначенні оптимальних чисельних характеристик виробничих ресурсів транспортного вузла.

Ключові слова: регіональні системи, логістичне управління, транспортний вузол, матеріальний потік, гірничодобувне підприємство

\section{Повышение эффективности процессов переработки продукции горнодобывающих предприятий в транспортных узлах}

$$
\begin{gathered}
\text { Я. Литвинова }{ }^{1}, \text { К. Носаль-Хой르, К. Солецка }{ }^{2}, \\
\text { И. Таран }
\end{gathered}
$$

1 - Национальный технический университет «Днепровская политехника», г. Днепр, Украина, e-mail: $\underline{\operatorname{taran} 7077 @}$ gmail.com

2 - Краковский технический университет, г. Краков, Польша, e-mail: knosal@pk.edu.pl

Цель. Повышение эффективности процессов перегрузки продукции горнодобывающих предприятий в транспортных узлах. Обоснование направлений оптимизации процессов логистического управления и оптимальных характеристик производственных ресурсов и организационных воздействий при логистическом управлении в мультимодальном транспортном узле. Определение экономического эффекта от обоснования этих характеристик.

Методика. Для формализации объекта исследования применены методы математического моделирования и системный подход. Для разработки модели объекта исследования использованы методы имитационного моделирования. С целью определения зависимости критерия эффективности функционирования транспортного узла от параметров материальных потоков и многочисленных характеристик производственных ресурсов применены методы регрессионного анализа.

Результаты. На основании проведенного исследования предложено использовать удельный показатель эффективности, представляющий собой отношение прибыли от обслуживания клиентуры в транспортном узле к стоимости производственных ресурсов, задействованных в процессе обслуживания. На основании разработанной модели транспортного узла возможно решение поставленных задач по совершенствованию логистического управления и переработки продукции горнодобывающих предприятий в транспортных узлах.

Научная новизна. Предложен подход к совершенствованию логистического управления транспортным узлом за счет обоснования оптимальных параметров производственных ресурсов и выбора наиболее эффективного варианта технологического процесса обслуживания заказчиков.

Практическая значимость. Заключается в разработке подходов к определению наиболее эффективного варианта обслуживания материальных потоков, а также в определении оптимальных многочисленных характеристик производственных ресурсов транспортного узла.

Ключевые слова: региональные системы, логистическое управление, транспортный узел, материальный поток, горнодобывающие предприятие

Recommended for publication by V.V.Sliesariev, Doctor of Technical Sciences. The manuscript was submitted 11.04.19. 